\title{
Estimating And Analyzing The Cost Efficiency Of Subchapter S Banks
}

Russ Kashian, University of Wisconsin Whitewater, USA

Richard Cummings, University of Wisconsin Whitewater, USA

Yannan Wang, University of Wisconsin Whitewater, USA

\begin{abstract}
This paper strives to evaluate the economic performance of Subchapter S Financial Institutions in Wisconsin. While there is a limited collection of research regarding Subchapter S banks, this paper expands the literature by investigating this research into their $x$ efficiency. This study measures performance differentials of Subchapter $S$ banks against banks organized as $C$ Corporations of similar size. The purpose of this paper is to determine the extent to which having this form of flow through ownership impacts efficiency levels.
\end{abstract}

Keywords: data envelopment analysis; subchapter S banks; bank efficiency; ownership

\section{INTRODUCTION}

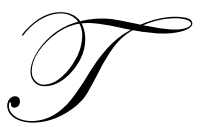

he focus and drive of efficiency within the financial sector continues to be an area of consideration for both researchers and practitioners. A fundamental analysis of how well revenues are squeezed out of a basket of inputs is part and parcel to the soul of efficiency analysis. While financial services markets have changed dramatically over the past two decades, the underlying role of the banking industry is fundamentally unchanged; the banking industry is still a life-blood of modern trade and commerce, serving as a major source of financial intermediation. This mix of innovation and change within the sector and the historic responsibility of the industry draw attention to evaluate whether banks operate efficiently. This paper focuses on one innovation and its impact on efficiency within the traditional industry. The development that occurred in the past twenty years is the potential for banks to assume an alternative form of ownership, Subchapter S rather than the traditional C Corporation.

Numerous studies have created the academic foundation for an examination of the efficiencies of banking industries and other financial institutions. During the 1990s, there were 130 published studies applying frontier efficiency analysis to financial institutions across 21 countries (Berger and Humphrey, 1997). The majority of those studies tested the relationship between bank efficiency and deregulation, consolidation, bank size, location, specialization, business cycle and macro economic factors. However, there has not been a study which analyzes the efficiency of different ownership forms of banks. The purpose of this paper is to fill that gap by examining the extent to which bank efficiency is influenced by two ownership forms and their different tax treatments.

The two ownership forms are corporations that elect to be taxed as a Subchapter S corporation as opposed to those corporations that do not make this election. Subchapter S ( $\S 1361$ to 1363 of the Internal Revenue Code (IRC)) is an ownership form that retains the corporate envelope and protection, while allowing treatment as a partnership for tax purposes. It eliminates the double taxation of corporate profits. One requirement of this election is a limited stockholder base (the number of unique stockholders is limited to 100 or fewer). This paper hypothesizes that, due to an agency effect, Subchapter $\mathrm{S}$ banks are more efficient than banks with a traditional corporate structure.

In this study, the aspect of efficiency of particular interest focuses on x-efficiency, which measures the managerial ability to control costs or to maximize revenue (Berger et al., 1993). The overall (economic) efficiency 
includes both technical efficiency, which measures a firm's ability to obtain maximum output by using a given set of inputs, and allocative efficiency, which reflects a firm's ability to utilize inputs to maximize outputs (Farrell, 1957).

\section{LITERATURE REVIEW}

\section{The Banking Ownership Form Study}

A comprehensive look at the differences in profitability between banks of different corporate structure (Westort, Kashian, and Cummings, 2010) recently used Call Report Data of Wisconsin banks, which were collected by SNL Securities, and applied dividend ratio and accounting return on assets (ROA) as two measures of performance to compare the profitability of Subchapter S banks and traditional C corporation banks. They argued that because Subchapter S banks pay less tax at corporate level, the owners will receive a higher rate of return to pay out dividends at higher rate; in addition, the flow through impact of the tax status encourages the firms to pay higher dividend as a compensation for the increased personal taxes to the shareholders. Moreover, due to the agency effects, Subchapter $\mathrm{S}$ banks will result in better performance and higher profitability. By using before tax profit as the dependent variable, they found Subchapter S banks did show higher rates of return and were more profitable as measured by ROA. However, when taxes were taken into account, there was no practical difference in profitability between the two types of corporate structure.

\section{Banking Efficiency Concepts And Measurement Methods}

The most important decision in measuring financial institution efficiency is to choose a concept to follow according to the question being addressed. Berger and Mester examined the three most important economic efficiency concepts- cost, standard profit, and alternative profit efficiencies (Berger and Mester, 1997). The cost efficiency measures a bank's cost and compares it to the best practice bank's cost by using the same output bundle under the same condition. This efficiency measure shows the proportion of costs or resources that are used efficiently by the bank. The standard profit efficiency sets a particular level of input prices and output prices to examine a bank's maximum possible profit. It is considered to be a better concept for taking the overall performance of a firm into account when compared to the cost efficiency concept. The alternative profit efficiency tests a bank's maximum profit by giving its output levels instead of its output prices. Its dependent variables are the same as those under the standard profit concept; also, it employs the same exogenous variables as the cost efficiency concept.

When referring to how to choose the appropriate inputs and outputs to measure bank efficiency, Berger and Humphrey analyzed three alternative methods of choosing bank outputs (Berger and Humphrey, 1997). First, under the asset approach, loans and other assets are considered as bank outputs and deposits and other liabilities are inputs since banks are only considered as financial intermediaries between liability holders and those who receive bank funds. Second, the user cost approach uses the net contribution of a financial product to a bank as the base of considering it as an input or output. A financial instrument is considered as an input if the returns on asset exceed the opportunity cost of funds or if the financial costs of a liability are less than the opportunity cost. Third, the valueadded approach doesn't distinguish inputs from outputs in a mutually exclusive way. If one category has substantial value added, using external sources of operating costs, then it is considered as an important output. Otherwise, it is treated either as unimportant outputs, intermediate products, or inputs, depending on the specifics of the category.

There are four estimation techniques to measure financial institution efficiency and each technique has its adherents and opponents. The techniques are Data Envelopment Analysis, (DEA), Stochastic Frontier Approach, Thick Frontier Approach and Distribution-Free Approach. These methods can be further divided into two categories, one is nonparametric linear programming approaches, and the other is parametric econometric approaches. The major difference among those approaches is the way they handle random error and their assumptions regarding the shape of the efficient frontier. DEA is the main non parametric approach and the most common efficiency estimation technique. The other three methods are all part of a parametric category. 


\section{The Banking Efficiency Studies}

There are many studies which have been done applying DEA methodology to banks in different countries all over the world in the past two decades. In many respects, these studies tour the world in their analysis of banking efficiency. For example, in an examination of Australian banks, it was found that the overall efficiency for Australian banks is lower than those in European countries and in the United States (US), (Sathye, 2001). This research also indicated that the technical component was more important than the allocative component as a source of overall inefficiency. In a study of the technical efficiency and scale efficiency in the Italian banking industry, it was revealed the inefficiency is best explained by productive specialization, size and, to some extent, by location (Favero and Papi, 1995). Ten years later, Tomova pooled the data from banks in different parts of the European Union, (EU) and the accession countries under a common frontier and compared the efficiency of those banks in obtaining the objectives of revenue generation and financial intermediation. The research shows that banks in the East tend to have lower efficiency scores with respect to both sets of objectives when controlling for a number of country and bank specific variables. (Tomova, 2005). In an evaluation of the productive efficiency and performance of US commercial banks, it was found the efficiencies of the banks that operate in varying economic conditions can mediate the impact to some extent (Barr, Killgo, Siems, and Zimmel, 2002). Research that focused on the relationship between financial sector reforms and the efficiency of banking in Pakistan indicated that the reforms have reduced the share of public sector banks in Pakistan. Nevertheless, efficiency of all public sector commercial banks that are privatized during the reform process has been improved, so the the reforms successfully improved the efficiency of the domestic commercial banks in Pakistan (Qayyum, 2005). An analysis of Pakistan's commercial banks suggested the same X-efficiency findings during the period of 1998 to 1999 (Akhtar, 2002)

Some researchers recently have studied Islamic banks and their efficiency. Hassan investigated the cost, profit, revenue and X-efficiency of Islamic banks in the world by using DEA methodology and revealed the Islamic banking industry is relatively less efficient compared to their conventional counterparts in other parts of the world. Moreover, the major source of cost efficiency is due to technical efficiency rather than allocative efficiency, which suggests the Islamic banks operated in overall regulatory environments that were not very supportive of their operations (Hassan, 2003). The similar outcomes can be found in a study of Islamic banking (Mokhtar, Abdullah, and Al-Habshi, 2006). They applied the Stochastic Frontier Approach and revealed that, on average, the efficiency of the overall Islamic banking industry has increased during the period of study while that of conventional banks remained stable over time. However, the efficiency level of Islamic banking is still lower than that of conventional banks. The study also reveals that full-fledged Islamic banks are more efficient than Islamic windows, while Islamic windows of foreign banks to be more efficient than those of domestic banks (Mokhtar, Abdullah, Al-Habshi, 2006). These Islamic windows are established by conventional banks of a Muslim country as a first as a method to offer Islamic lending practices by a conventional bank. These windows are based on the belief that interest is prohibited, but because immediate and/or total operational conversion is undesired, this policy is undertaken on gradual basis and a separate window or unit is established as a first step.

There are still many studies which applied the efficiency methodologies to some non-banking financial institutions. Frontier efficiency analysis was used to examine scale economies and efficiency in the Spanish insurance industry and found that the deregulation and consolidation did improve the efficiency in the Spanish insurance market (Cummins and Rubio-Misas, 2006). DEA methodology was applied to analyze the X-efficiency and allocative efficiency of credit union mergers. The outcome showed that a credit union merger may not gain improved X-efficiency and allocative efficiency (Garden and Ralston, 1999). 


\section{HYPOTHESES}

The purpose of this paper is to examine the efficiency of different ownership forms of banks. According to previous studies, more efficient banks should tend to have lower expenses, fixed assets, purchased funds, nonperforming loans, and loans-to-assets. Meanwhile, they should also tend to have higher income, earning assets, and return on average assets (ROA). We found in our previous study that Subchapter S banks tend to be more profitable than traditional corporate banks as measured by ROA. However when taxes are taken into account, there is no practical difference in profitability between the two types of corporate structure. Due to the results of this recent research (Westort, Kashian, and Cummings, 2010), this paper will not conduct a two-stage envelopment analysis (in which the efficiency scores are then used in a regression with the inputs and outputs). This would unnecessarily repeat the earlier research. Rather, we are interested in testing whether Subchapter $\mathrm{S}$ banks run more efficient than their traditional counterpart.

Berger and Humphrey (1997) suggested the intermediation approach is the best method to evaluate the entire bank when doing frontier studies in banking. Since it considers interest expense (income paid to depositors), which often accounts for one-half to two-thirds of total costs. Under intermediation approach, banks are considered as intermediary entities, which convert inputs into outputs. Reviewing the prior studies of banking efficiency, we notice that most of the studies have adopted the intermediation approach. As a result, we apply the most widely used approach to our study here.

The results created in this analysis involve measuring the performance of each firm in the industry relative to "best practice" efficient frontiers. It is critical to recognize that the resulting scores are relative. Although a bank may receive an efficiency score of $100 \%$, this is simply stating that it is creating the most outputs with a given amount of inputs relative to other banks in the sample. This does not mean that the bank is "efficient" in a business sense; it is simply more efficient than its competition. Efficiency scores vary between zero and one, with the efficient firms having efficiencies equal to one and inefficient firms having efficiencies between zero and one. If a bank has an efficiency score of $80 \%$, the bank could improve their cost efficiency by $20 \%$. An alternate way to look at this issue is to recognize that the bank could have used only $80 \%$ of the inputs actually used to produce the same level of inputs. In other words, it spent $20 \%$ more than a competitor to obtain similar results.

Technical Efficiency refers to the transfer of physical inputs (such as buildings and employees) into output. Technical efficiency for a given firm is defined as the ratio of the input usage of a fully efficient firm producing the same output vector to the input usage of the firm under consideration. Allocative efficiency measures the firm's success in choosing the cost minimizing combination of inputs. Therefore, to be fully cost efficient, a firm must be both technically and allocatively efficient. This paper estimates efficient production and cost frontiers, providing measures of cost, technical, and allocative efficiency for each firm in our sample. Cost Efficiency is the product of technical and allocative efficiencies. Cost efficiency (also known as Economic Efficiency) for a given firm is defined as the ratio of the costs of a fully efficient firm (i.e., a firm operating on the efficient cost frontier) with the same output quantities and input prices to the given firm's actual costs. As noted earlier, one minus a firm's efficiency ratio provides a measures of the proportion by which costs could be reduced if the firm were operating on the cost frontier. Firms achieve cost efficiency by adopting the best technology (becoming technically efficient) and choosing the optimal mix of inputs (becoming allocatively efficient). A fundamental addition to cost efficiency is the inclusion of input prices.

While there has been a progression in the development of measuring efficiency using DEA, there is no standard, agreed upon list of inputs and outputs. As a result, this paper has chosen to conduct the analysis using common inputs and outputs culled from a variety of papers (Sathye, 2001). Employing an intermediation approach (Casu and Molyneux, 2003; Isik and Hassan, 2002; Pasiouras, 2007), we assume that banks act as financial intermediates that collect purchased funds and use labor to transform these funds to loans and other assets. The three inputs are: fixed assets (X1), deposits (X2) and number of employees (X3). The two outputs are: loans (Y1), and Demand Deposits (Y2). These inputs and outputs are necessary to calculate the Technical Efficiency of the bank. 
In order to calculate the allocative efficiency, we require the prices of the inputs used to fund the outputs. Following Sathye (2001) we used the Price of Labor $\left(\mathrm{P}_{1}\right)$, the Price of Capital $\left(\mathrm{P}_{2}\right)$ and the Price of Loanable Funds $\left(\mathrm{P}_{3}\right)$. The Price of Labor was calculated by dividing the employee salary expense by the total number of employees. The Price of Capital was determined by dividing the Expense Statements cost of Premises and Fixed Assets by the Balance Sheets net value of Premises and Fixed Assets. The Price of Loanable Funds was calculated by taking the sum of interest expenses on deposits and other loanable funds and dividing it by loanable funds.

\section{DATA}

The data for this analysis are from the regulatory reports of the 249 banks headquartered in the State of Wisconsin. These banks existed throughout the duration of the analysis (from 1998 to 2009). The dataset is based on the performance and ownership characteristics of these Federal Deposit Insurance Corporation, (FDIC), and insured banks. Due to this FDIC relationship, all banks (publicly owned and privately owned) are required to provide consistent and comparable financial reports to the public. This creates a database in which all privately held institutions' financial statements are available. This analysis includes all banks, regardless of size. As a result, extremely large banks (such as Marshall \& Ilsely with \$50 Billion in assets in 2009) are included in an analysis with very small banks (such as Milton Savings Bank with $\$ 17$ million in assets in 2009). Rather than eliminating the large banks, which would require an arbitrary determination of size, we ran the efficiency analysis twice. We ran the analysis with all banks headquartered in Wisconsin. We then eliminated all banks over $\$ 1$ billion in 2009 . It is critical to note that there was no material difference in the efficiency relationships for these two groups of banks. As a result, we kept all banks in the final database. 
The descriptive statistics of selected sample have been presented in Table 1 .

Table 1: Sample Descriptive Statistics

\begin{tabular}{|l|c|c|c|}
\hline & Minimum & Maximum & Standard \\
Deviation
\end{tabular}

The asset size statistic, comparing $\mathrm{C}$ corporations with subchapter $\mathrm{S}$ corporations, is shown in Table 2, which indicates that $\mathrm{C}$ corporations have bigger asset size than $\mathrm{S}$ corporations.

Table 2: Asset Size By Corporation Type

\begin{tabular}{|c|c|c|c|c|c|c|c|c|}
\hline \multirow[b]{2}{*}{ Year } & \multicolumn{4}{|c|}{ C Corporation-Asset Size (000) } & \multicolumn{4}{|c|}{ S Corporation- Asset Size } \\
\hline & $\mathbf{N}$ & Average & Minimum & Maximum & $\mathbf{N}$ & Average & Minimum & Maximum \\
\hline 1998 & 221 & $\$ 168,697$ & $\$ 11,792$ & $\$ 9,414,827$ & 28 & $\$ 84,355$ & $\$ 20,787$ & $\$ 368,597$ \\
\hline 1999 & 215 & $\$ 195,059$ & $\$ 11,946$ & $\$ 10,826,686$ & 34 & $\$ 88,017$ & $\$ 19,587$ & $\$ 461,039$ \\
\hline 2000 & 212 & $\$ 214,847$ & $\$ 12,840$ & $\$ 12,864,999$ & 37 & $\$ 122,687$ & $\$ 20,805$ & $\$ 772,872$ \\
\hline 2001 & 209 & $\$ 313,594$ & $\$ 13,728$ & $\$ 25,811,222$ & 40 & $\$ 192,388$ & $\$ 20,098$ & $\$ 1,589,371$ \\
\hline 2002 & 205 & $\$ 340,427$ & $\$ 14,797$ & $\$ 28,166,870$ & 44 & $\$ 211,419$ & $\$ 12,826$ & $\$ 2,101,740$ \\
\hline 2003 & 199 & $\$ 382,276$ & $\$ 18,167$ & $\$ 29,994,124$ & 50 & $\$ 213,632$ & $\$ 14,335$ & $\$ 2,257,941$ \\
\hline 2004 & 195 & $\$ 428,365$ & $\$ 18,071$ & $\$ 34,184,289$ & 54 & $\$ 231,136$ & $\$ 13,286$ & $\$ 2,562,859$ \\
\hline 2005 & 191 & $\$ 512,630$ & $\$ 18,129$ & $\$ 38,901,483$ & 58 & $\$ 258,659$ & $\$ 14,963$ & $\$ 2,878,696$ \\
\hline 2006 & 186 & $\$ 575,207$ & $\$ 17,777$ & $\$ 48,017,386$ & 62 & $\$ 291,678$ & $\$ 16,120$ & $\$ 4,011,216$ \\
\hline 2007 & 179 & $\$ 640,362$ & $\$ 17,882$ & $\$ 52,720,915$ & 70 & $\$ 298,075$ & $\$ 17,503$ & $\$ 4,677,827$ \\
\hline 2008 & 175 & $\$ 684,811$ & $\$ 17,908$ & $\$ 55,486,249$ & 74 & $\$ 326,839$ & $\$ 21,179$ & $\$ 5,386,439$ \\
\hline 2009 & 176 & $\$ 681,924$ & $\$ 17,159$ & $\$ 50,253,578$ & 73 & $\$ 269,862$ & $\$ 21,360$ & $\$ 1,858,067$ \\
\hline
\end{tabular}


Table 3 compares the scores of technical, allocative, and overall cost efficiency between $\mathrm{C}$ corporations and S corporations.

Table 3: Efficiency Scores By Corporation Type

\begin{tabular}{|c|c|c|}
\hline & C Corporation & S Corporations \\
\hline Year & Technical Efficiency & Technical Efficiency \\
\hline 1998 & $75.16 \%$ & $79.81 \%$ \\
\hline 1999 & $75.92 \%$ & $80.93 \%$ \\
\hline 2000 & $79.24 \%$ & $82.72 \%$ \\
\hline 2001 & $70.01 \%$ & $73.54 \%$ \\
\hline 2002 & $72.08 \%$ & $73.83 \%$ \\
\hline 2003 & $74.91 \%$ & $75.36 \%$ \\
\hline 2004 & $68.01 \%$ & $67.92 \%$ \\
\hline 2005 & $72.81 \%$ & $75.22 \%$ \\
\hline 2006 & $68.78 \%$ & $69.63 \%$ \\
\hline 2007 & $66.72 \%$ & $68.98 \%$ \\
\hline 2008 & $68.73 \%$ & $70.39 \%$ \\
\hline 2009 & $66.99 \%$ & $68.15 \%$ \\
\hline Average & $71.61 \%$ & $73.87 \%$ \\
\hline Year & Allocative Efficiency & Allocative Efficiency \\
\hline 1998 & $37.85 \%$ & $38.49 \%$ \\
\hline 1999 & $40.36 \%$ & $39.76 \%$ \\
\hline 2000 & $46.39 \%$ & $44.99 \%$ \\
\hline 2001 & $16.06 \%$ & $16.20 \%$ \\
\hline 2002 & $42.34 \%$ & $44.90 \%$ \\
\hline 2003 & $22.76 \%$ & $23.70 \%$ \\
\hline 2004 & $42.40 \%$ & $42.25 \%$ \\
\hline 2005 & $29.72 \%$ & $29.22 \%$ \\
\hline 2006 & $26.37 \%$ & $25.25 \%$ \\
\hline 2007 & $40.23 \%$ & $40.03 \%$ \\
\hline 2008 & $36.36 \%$ & $36.31 \%$ \\
\hline 2009 & $30.40 \%$ & $31.04 \%$ \\
\hline Average & $34.27 \%$ & $34.35 \%$ \\
\hline Year & Cost Efficiency & Cost Efficiency \\
\hline 1998 & $28.45 \%$ & $30.72 \%$ \\
\hline 1999 & $30.64 \%$ & $32.18 \%$ \\
\hline 2000 & $36.76 \%$ & $37.22 \%$ \\
\hline 2001 & $11.24 \%$ & $11.91 \%$ \\
\hline 2002 & $30.52 \%$ & $33.15 \%$ \\
\hline 2003 & $17.05 \%$ & $17.86 \%$ \\
\hline 2004 & $28.84 \%$ & $28.70 \%$ \\
\hline 2005 & $21.64 \%$ & $21.98 \%$ \\
\hline 2006 & $18.14 \%$ & $17.58 \%$ \\
\hline 2007 & $26.84 \%$ & $27.61 \%$ \\
\hline 2008 & $24.99 \%$ & $25.56 \%$ \\
\hline 2009 & $20.36 \%$ & $21.15 \%$ \\
\hline Average & $24.62 \%$ & $25.47 \%$ \\
\hline
\end{tabular}

As we can see from Table 3 that all the C corporations have an average score of $71.61 \%$ for the technical efficiency within the 12 years period from 1998 to 2009 . This is lower than $73.87 \%$ of the average score of technical efficiency for $\mathrm{S}$ corporations. It is worthy to note that $\mathrm{S}$ corporations have higher technical efficiency in every year except 2004. As a result, $\mathrm{S}$ corporations are generally more technically efficient than $\mathrm{C}$ corporations. 
As for allocative efficiency, S corporations only have higher scores in year of 1998, 2001, 2002, and 2003. In the remaining years, $\mathrm{C}$ corporations have slightly higher allocative efficiency scores. However, the average score of allocative efficiency for $\mathrm{C}$ corporations is $34.27 \%$, which is a little lower than the average score of $34.35 \%$ for S corporations. Another interesting point we find is that the allocative efficiency of banks in the state of Wisconsin in the sample was much lower than their technical efficiency. Allocative efficiency relates to the firms' choice of combination of inputs to minimize the cost. Consequently, in order to improve allocative efficiency, banks may need to reconstruct their fee structure to fully reflect underlying costs.

Since cost efficiency is the product of technical and allocative efficiency and S corporations have higher average scores for both technical and allocative efficiency, S corporations must have a higher score of the overall cost efficiency, as indicated in table 3. S corporations have higher cost efficiency scores than its counterpart in all the years from 1998 to 2009 except in 2004 and 2006. The average score of cost efficiency is about $25.47 \%$ for S corporations while $24.62 \%$ for $\mathrm{C}$ corporations. As a result, $\mathrm{S}$ corporations do have both technical and allocative efficiency and the overall cost efficiency. However, this advantage of operating more efficient is not significant as we expected.

The earlier Subchapter S paper found a profit difference between $\mathrm{S}$ corporations and C corporations. However, the additional profit of $\mathrm{S}$ corporations was significant but not material. The efficiency results we find here are compared with the prior findings: There is a slight increase in efficiency for the Subchapter S Corporation. Bringing these two results together, it is reasonable to expect that the slight difference in profitability and the slight efficiency advantage held by the Subchapter S Corporation are consistent.

\section{ABOUT THE AUTHORS}

Russ Kashian has conducted an extensive research in economic development and published in a wide variety of journals. Russ Kashian is a Professor of Economics at the University of Wisconsin Whitewater. He also serves as a Specialist for the University of Wisconsin Extension and is co-founder of the Fiscal and Economic Research Center at the University of Wisconsin Whitewater. Professor Kashian's major fields of research are regional planning and regional financial institutions. His current research is focused on the regional distribution and economic impact of Foreclosures and Sheriff's Sales on the Wisconsin Real Estate Market.

Richard Cummings is an associate professor of Accounting at the University of Wisconsin-Whitewater. He teaches individual taxation and MBA- Financial Accounting. His research interests includes: empirical studies in horizontal equity in individual taxation, the effect of Subchapter $\mathrm{S}$ election in community banks, international accounting, and accounting education.

Yannan Wang received her BS in Supply Chain \& Logistics from Shanghai Maritime University and is currently pursuing her Master Degree in Accounting from University of Wisconsin-Whitewater.

\section{REFERENCES}

1. Akhtar, M.H., and Husnain Bokhari, S.M. (2002), X-efficiency Analysis of Commercial Banks in Pakistan: A Preliminary Investigation, European Journal of Scientific Research, Vol. 10 No.2, pp. 78-91.

2. Barr, R.S., Killgo, K.A., Siems, T.F., and Zimmel, S. (2002), Evaluating the Productive Efficiency and Performance of U.S. Commercial Banks, Managerial Finance, Vol. 28 No. 8, pp. 3-25.

3. Berger, A.N., and Humphrey, D.B. (1997), Efficiency of financial institutions: International survey and directions for future research, European Journal of Operational Research, pp. 175-212.

4. Berger, A.N., Hancock, D., and Humphrey, D.B. (1993) Bank efficiency derived from the profit function, Journal of Banking and Finance, Vol. 17, pp. 317-347.

5. Berger, A.N. and Mester, L.J. (1997), Inside the black box: What explains differences in the efficiencies of financial institutions, Journal of Banking \& Finance Vol. 21, pp. 895-947.

6. Casu, B., and Molyneux, P. (2003), A Comparative Study of Efficiency in European Banking, Applied Economics Vol. 35, pp. 1865-1876. 
7. Cummins, J.D., and Rubio-Misas, M. (2006), Deregulation, Consolidation, and Efficiency: Evidence from the Spanish Insurance Industry, Journal of Money, Credit, and Banking, Vol. 38, No. 2, pp. 323-355.

8. Farrell, M.J. (1957), The Measurement of Productive Efficiency, Journal of the Royal Statistical Society Series A, Vol. 120, No. 3, pp. 253-290.

9. Favero, C.A. and Papi, L. (1995), Technical efficiency and scale efficiency in the Italian banking sector: a non-parametric approach, Applied Economics Vol. 27, pp. 385-395.

10. Garden, K.A. and Ralston, D.E. (1999), The x-efficiency and allocative efficiency effects of credit union mergers, Journal of International Financial Markets, Institutions and Money Vol. 9, pp. 285-301.

11. Hassan, M.K. (2005), The Cost, Profit, and X-Efficiency of Islamic Banks, Paper presented at The $12^{\text {th }}$ ERF Annual Conference, December 19-21, 2005, Egypt.

12. Isik, I., and Hassan, M.K. (2002), Technical, Scale and Allocative Efficiencies of Turkish Banking Industry, Journal of Banking \& Finance, Vol. 26, pp. 719-766.

13. Mokhtar, H.S., Ahmad Abdullah, N., and Al-Habshi, S.M. (2006), Efficiency of Islamic banking in Malaysia: A stochastic frontier approach, Journal of Economic Cooperation Vol. 27, No. 2, pp. 37-70.

14. Pasiouras, F., Sifodaskalakis, E., and Zopounidis, C. (2007), Estimating and Analyzing the Cost Efficiency of Greek Cooperative Banks: An Application of Two-Stage Data Envelopment Analysis, working paper, School of Management, University of Bath, December, 2007.

15. Qayyum, A. (2007), Financial Sector Reforms and the Efficiency of Banking in Pakistan, South Asian Network of Economic Research Institutes (SANEI).

16. Sathye, M. (2001), X-efficiency in Australian banking: An empirical investigation, Journal of Banking \& Finance Vol. 25, pp. 613-630.

17. Tomova, M. (2005), X-efficiency of European Banking-Inequality and Convergence, Paper presented at EcoMod 2005-International Conference on Policy Modeling, June 29-July 1, 2005, Istanbul.

18. Westort, P., Kashian, R., and Cummings, R. (2010), Does ownership form in community banking impact profitability?, Managerial Finance, Vol.36, No.2, pp. 122-133. 
NOTES 